CORRECTION

https://doi.org/10.1038/s41586-019-0929-5

\title{
Author Correction: GABA receptor signalling mechanisms revealed by structural pharmacology
}

Simonas Masiulis, Rooma Desai, Tomasz Uchański, Itziar Serna Martin, Duncan Laverty, Dimple Karia, Tomas Malinauskas, Jasenko Zivanov, Els Pardon, Abhay Kotecha, Jan Steyaert, Keith W. Miller \& A. Radu Aricescu

Correction to: Nature https://doi.org/10.1038/s41586-018-0832-5, published online 02 January 2019.

In Fig. $5 \mathrm{~b}$ and $5 \mathrm{~d}$ of this Article, the arrows showing transmembrane domain rotations were inadvertently pointing anticlockwise instead of clockwise. Similarly, 'anticlockwise' should have been 'clockwise' in the sentence 'This conformational change of the ECD triggers a clockwise rotation of the TMD.' In addition, in Extended Data Table 1, the units of the column 'Model resolution' should have been $\AA$ instead of $\AA^{2}$. The original Article has been corrected online. 